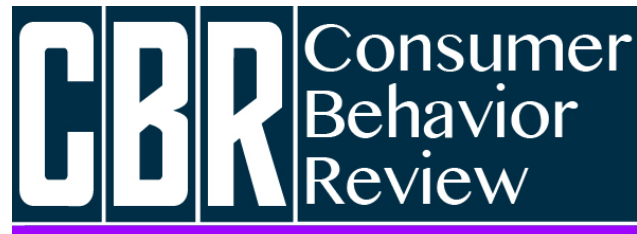

Revista Comportamento do Consumidor
Enes, Y., Lima, T., Demo, G., \& Scussel, F. (2021). The Intellectual Structure of Relationship Marketing Scientific Field: Proposing new avenues of research from a systematic review. Consumer Behavior Review, 5(1), 110-127.
ISSN: 2526-7884

Editor: Prof. Dr. Marconi Freitas da Costa

E-mail: cbr@ufpe.br
Evaluation: Double blind review

Received: May 25, 2020

Accepted: November 11, 2020

\title{
THE INTELLECTUAL STRUCTURE OF RELATIONSHIP MARKETING SCIENTIFIC FIELD: PROPOSING NEW AVENUES OF RESEARCH FROM A SYSTEMATIC REVIEW
}

A Estrutura Intelectual do Campo Científico de Marketing de Relacionamento: Proposição de novas avenidas de pesquisa a partir de uma revisão sistemática

Yuri Enes ${ }^{1}$

ORCID: https://orcid.org/0000-0003-2667-5754

E-mail: yuri.odaguiri@gmail.com

Talia Lima ${ }^{1}$

ORCID: https://orcid.org/0000-0003-0940-5234

E-mail: talitalsadm@gmail.com

Gisela Demo ${ }^{1}$

ORCID: https://orcid.org/0000-0003-1864-0471

E-mail: giselademo@unb.br

Fernanda Scussel ${ }^{2}$

ORCID: https://orcid.org/0000-0001-7953-6710

E-mail: fbcardoso@gmail.com

${ }^{1}$ Universidade de Brasília, Brasília, Brasil

${ }^{2}$ Universidade Federal de Santa Catarina, Florianópolis, Brasil

\begin{abstract}
We aim to analyze the evolution and the social and intellectual structure of relationship marketing/CRM scientific field and develop a research agenda. We performed a systematic review and bibliometric analysis of 290
\end{abstract}

Resumo
O objetivo deste artigo é analisar a evolução e
$\begin{array}{lcrr}\text { a estrutura } & \text { social e intelectual do campo } \\ \text { científico do } & \text { do } & \text { marketing } & \text { de } \\ \text { relacionamento/CRM e } & \text { desenvolver } & \text { uma } \\ \text { agenda de pesquisa. Realizou-se uma revisão }\end{array}$


articles published between 2015 and 2020 . The social structure of the field shows the concentration of publication in developed countries and the predominance of the NorthAmerican approach and its focus on consumer centricity. Five research perspectives compose the intellectual structure of relationship marketing scientific field: business-tobusiness, customer loyalty, adoption and implementation strategies, theoretical developments and digital relationship marketing. We recommend scholars to address relational studies in emerging economies and the role of sociocultural elements in relationship marketing strategies; the impact of social media in consumers and firms relational dynamics; the multichannel context; and the rise of consumption journey as an opportunity to develop relationships in the multiple touchpoints between consumers and firms during the stages of consumption experience.

Keywords: Relationship Marketing; Customer Relationship Management; Systematic Review; Research Agenda. sistemática e análise bibliométrica de 290 artigos publicados entre 2015 e 2020. A estrutura social do campo mostra a concentração de publicações nos países desenvolvidos e a predominância da abordagem norte-americana e seu foco na centralidade do consumidor. Cinco perspectivas de pesquisa compõem a estrutura intelectual do campo científico do marketing de relacionamento: business-tobusiness, fidelização de clientes, estratégias de adoção e implementação, desenvolvimentos teóricos e marketing de relacionamento digital. Recomendamos que pesquisadores abordem estudos relacionais em economias emergentes e o papel dos elementos socioculturais nas estratégias de marketing de relacionamento; o impacto das mídias sociais na dinâmica relacional entre consumidores e empresas; o contexto multicanal; e a jornada de consumo como uma oportunidade para desenvolver relacionamentos nos múltiplos pontos de contato entre consumidores e empresas durante os estágios da experiência de consumo.

Palavras-chave: Marketing de Relacionamento, Customer Relationship Management; Revisão Sistemática; Agenda de Pesquisa.

\section{INTRODUCTION}

The increasing imperative of competitiveness requires from organizations a constant focus on consumers' needs and desires, adopting consumer-centric approaches in order to deliver customer value and, from this, achieve positive results such as profitability and market positioning (Ross, 2009; Spottke, Eck, \& Wulf, 2016). In the top of consumer centricity agenda, there are three important streams of research to be explored: the need of consumer driven orientation, co-creation of value and relational benefits (Spottle et al., 2016). In this context, relationship marketing arises as an organizational philosophy that enables firms to manage, develop and improve their interactions with consumers (Mishra \& Mishra, 2009; Venter \& van Rensburg, 2014) by transforming consumer information in decision-making processes, contributing to firms' positioning in the competitive scenario (Maçada, Brinkhues, \& Freitas Junior, 2019).

By combining the strategies of relationship marketing with the potential of information technologies, Customer Relationship Management (CRM) emerges as a strategic and holistic approach centered in the development of profitable and long-term relationships with customers, delivering superior consumer value and promoting relational benefits for both parts (Payne, 2012). CRM enables firms to identify consumers' specific characteristics, a crucial input to the creation of customized and effective marketing strategies (Campbell, 2003), positively affecting firms' performance (Wang \& Feng, 2012). Besides that, gadgets and technologies connected to resource integration and data analysis 
have become an important asset to organizations, increasing the academic interest in understanding the antecedents, the potential and the implications of such reality (Heck, 2019), which highlights the potential use of CRM strategies when aligned with the organization's interests.

As stated by Frow and Payne (2009), although relationship marketing and CRM carry differences in their scope, both constructs focus on strategic management, being CRM an element of the broader body of knowledge of relationship marketing. According to these scholars, the terms relationship marketing and CRM are used interchangeably and, since the 1990's, they have been a content of growing academic interest. Many researchers have mapped the literature on relationship marketing/CRM over the years, indicating an increasing trend that seems to follow the transformations of managerial practice and the changes in consumer behavior (Araújo, Pedron, \& Picoto, 2018; Das, 2009; Demo, Fogaça, Ponte, Fernandes, \& Cardoso, 2015; Mohammadhossein \& Zakaria, 2012; Ngai, 2005; Scussel, Petroll, Semprebom, \& Rocha, 2017).

The present business scenario is characterized by the growth of online competition (Kleineberg \& Boguña, 2016), the impact of social media in customer-firm dynamics (Malthouse, Haenlein, Skiera, Wege, \& Zhang, 2013; Trainor, Andzulis, Rapp, \& Agnihotri, 2014), the emergence of consumption experience (Lemon \& Verhoef, 2016; Scussel, 2019) and the impact of technology in consumer behavior (Roy \& Moorthi, 2017; Marriott, Williams, \& Dwivedi, 2017). This perspective demands the constant monitoring of the effect of such reality in the relationships between consumers and firms, also requiring further analysis from the scientific literature in order to understand the phenomena brought by these changes. We foresee these underexplored phenomena as literature gaps, with possibilities of influencing organizational studies and marketing and consumer behavior research. On that basis, mapping the scientific field, considered a paramount effort for advancing the research in a particular field (Zupic \& Carter, 2015), is a helpful path to comprehend the current state of the literature and identify empirical and theoretical gaps to be further addressed.

Therefore, the present paper aims to analyze the evolution and the social and intellectual structure of relationship marketing/CRM scientific field, in order to provide an overview of the current research field and to identify future avenues of investigation. From this, we build the major contribution of this paper, which is the development of a research agenda, shedding light into the major research gaps and dominant tendencies of this scientific field. This research agenda is valuable to guide scholars dedicated to consumer-centric studies, particularly those under a relational perspective.

\section{THEORETICAL BACKGROUND}

\section{Relationship Marketing (RM)}

Relationship marketing emerges as the outcome of a paradigm shift in marketing core concepts: from a transactional and monetary paradigm, marketing starts to embrace an approach centered in consumers, designing relational strategies based on the clients' needs and demands (Frow \& Payne, 2009; Grönroos, 1994, 2009; 2017; Sheth \& Parvatiyar, 2002; Payne \& Frow, 2005). This paradigm shift from a transactional to a relational perspective is the foundation of relationship marketing, context in which relational benefits, for both companies and consumers, are the main objective (Grönroos, 2009; 2017). Conceptually, relationship marketing is an integrated organizational effort to attract, maintain, reinforce and develop relationships with customers (Frow \& Payne, 2009; Berry, 1995; Morgan \& Hunt, 1994).

The rise of relationship marketing represented a significant transformation in organizational practices when literature pointed out that building relationship with customers in the long term is a source of sustainable competitive advantage (Veloutsou, Saren, \& Tzokas, 2002). Payne (1995) identified four main research groups on relationship marketing that were named as relationship marketing schools, integrating the theoretical foundations of each stream of research. First, there is the Anglo-Australian school, expanding the notion of relationship marketing as the interaction between consumer and firm to the integration of other stakeholders. The Scandinavian school of thought is influenced by service quality and service marketing theories. For its turn, the Industrial Marketing and Purchasing (IMP) Group has privileged the relationship between firms, focusing on the 
business-to-business (B2B) research. Lastly, the North-American school emphasizes the systematization of the concepts investigated under the relationship marketing umbrella, developing a theoretical framework based on consumer knowledge.

\section{Customer Relationship Management (CRM)}

A recent definition has shed light into relationship marketing as a business philosophy that promotes the interaction between customers and firms, its employees, partners and stakeholders, with the purpose of value creation for all the actors involved (Scussel et al., 2017). This conceptualization reveals the integrative nature of relationship marketing, which has been captured by researchers focused on Customer Relationship Management - CRM, a proposal combining the essence of relationship marketing and the use of information technology in a strategic and holistic perspective to achieve better results from the relationships with customers (Demo et al., 2015; Frow \& Payne, 2009). In other words, the responsibility in managing relationships with customers is now shared with the company as a whole, expanding the customer focus from the marketing department to all the organizational areas (Demo et al., 2015; Grönroos, 2009).

CRM is an organizational philosophy that aims to create, develop and strength relationship networks with the stakeholders of an organization (Benouakrim \& El Kandoussi, 2013). This means that CRM, in order to be successful, needs to generate opportunities in the use of information to better know the customers and implement relational strategies (Frow \& Payne, 2009; Payne \& Frow, 2005). However, CRM cannot be understood as a technological tool, being a strategic ideology that improves organizational practices (Reimann, Schilke \& Thomas, 2010).

Buttle and Maklan (2019) recognize the variety of terms literature embraces regarding CRM definitions and conceptualizations, explaining there are three ways to investigate this construct: (i) analytic, emphasizing data analysis processes; (ii) operational, with focus of service and marketing activities automatization; and (iii) strategic, concerning the role of CRM in consumer retention and relationship development. Hence, CRM studies shed light on the advantages of improving customer centricity, enabling fast and customized actions, in addition to the opportunity of consumer segmentation and the design of specific strategies in line with the knowledge company has about each group of consumers (Mohammadhossein \& Zakaria, 2012).

According to Frow and Payne (2009), relationship marketing is a broad concept covering the strategic management of relationships with customers and other organizational stakeholders, and CRM is the strategic management of relationships with customers using information technology. According to them, CRM is part of the relationship marketing concept, being a relational construct centered in strategic interactions with customers to generate value and relational benefits. Thus, the expected outcome from relationship marketing, which embodies CRM, is customer management, the strategic implementation of relational strategies, encompassing service, product development, sales force and personalization, for example (Frow \& Payne, 2009). Table 1 summarizes the distinction between the concepts of relationship marketing and CRM.

Table 1

Relationship marketing and CRM concepts' distinction

\begin{tabular}{lll}
\hline & Relationship marketing (RM) & $\begin{array}{l}\text { Customer Relationship Management } \\
\text { (CRM) }\end{array}$ \\
\hline “Strategic management of & $\begin{array}{l}\text { "Strategic management of relationships } \\
\text { relationships with all relevant } \\
\text { stakeholders" (Payne \& Frow, 2017, } \\
\text { p.12). }\end{array}$ & $\begin{array}{l}\text { with customers, involving appropriate use } \\
\text { of technology" (Payne \& Frow, 2017, p.12). }\end{array}$ \\
\hline Convergences & $\begin{array}{l}\text { The CRM fits with relationship marketing and is part of it. Both concepts are } \\
\text { primarily focused on relationship management (Payne \& Frow, 2017). }\end{array}$ \\
\hline \multirow{2}{*}{ Divergences } & $\begin{array}{l}\text { It is considered a theoretically } \\
\text { broader perspective, including } \\
\text { several relational strategies (Payne, } \\
\text { 2000). }\end{array}$ & $\begin{array}{l}\text { CRM is a relational strategy that focus on } \\
\text { the use of technology to manage customer } \\
\text { relationships (Payne, 2000). }\end{array}$ \\
\hline
\end{tabular}




\begin{tabular}{lll}
\hline & $\begin{array}{l}\text { When it comes to RM, some authors } \\
\text { have a holistic view of diverse }\end{array}$ & \\
& organizational relationships; & The meanings of CRM is still limited and \\
meanwhile others wish to de- & many companies still conceive CRM only as \\
emphasise all relationships except & a technological solution or a software \\
that of the customer-supplier dyad & (Demo, 2014). \\
& & \\
\hline
\end{tabular}

The rise of CRM in the early 1990's set the need of measurement instruments, and Wilson and Vlosky (1997) developed the seminal scale of CRM, addressing relationship management in the B2B market, followed by Sin, Tse and Yim (2005) and Agariya and Singh (2012). The B2C market, emphasizing the relationship between firms and customers, gained its first scale with the work of Rozzett and Demo (2010): the Scale of Relationship with Customers, a scientific instrument able to measure customer perception regarding the relational initiatives of companies in the B2C segment. This scale was cross-culturally validated in the United Stated (Demo \& Rozzett, 2013) and in France (Demo et al., 2017), confirming its internal structure. Additionally, Rozzett and Demo (2010) adapted and validated the scale in different market sectors in order to focus on the specific needs of the customers of each segment - theme parks (Vasconcelos \& Demo, 2012), beverages (Demo \& Lopes, 2014), electronic games (Demo, Batelli \& Albuquerque, 2015), communication (Demo et al, 2017), supermarket (Magrini \& Demo, 2017), airlines (Demo et al, 2018) and luxury brands (Scussel \& Demo, 2019).

Concerning literature reviews, we identified the article from Ngai (2005) as the seminal article mapping the scientific production on relationship marketing/CRM, covering works from 1992 to 2002 and demonstrating a growth perspective for CRM due to the combination between the relational approach and the potential of technology. Araújo et al. (2018) published the most recent review on CRM, considering articles from 2000 to 2015, confirming Ngai's (2005) expectations: CRM has become a content in the top of marketing studies' agenda. Araújo et al. (2018) also identified the main categories studies under the CRM body of knowledge, namely, methodologies for construct analysis, relationship marketing, service quality and loyalty, strategic orientation, practical implications and customer value. Besides that, Payne and Frow (2017) and Harker and Egan (2006) have also developed literature reviews outlining the emergence, growth and development of relationship marketing theory over the years. However, these reviews did not include a systematic review of the studied literature, which differentiates these works from ours. On the other hand, the study produced by Samiee, Chabowski and Hult (2015) presents a research agenda based on a literature review of 2013. Therefore, our study seeks to update and continue this research.

Literature reviews addressing relationship marketing/CRM indicate the need of further understanding of the antecedents and consequents of CRM, as well as its impact on other organizational variables, beyond the marketing literature, including mediation and moderation in complex models (Araújo et al., 2018; Das, 2009; Demo et al., 2015; Mohammadhossein \& Zakaria, 2012; Ngai, 2005; Scussel et al., 2017). The current research has focused on the strategic outcomes of CRM, but what else is there? Besides, conceptually, we still identify a misunderstanding between CRM as a holistic business approach and its technological implementation, which limits its benefits. Therefore, we consider that understanding the gaps of current research will contribute to the comprehension of the phenomenon, to the development of a stronger theoretical framework and to strength CRM strategic role in improving organizational results.

\section{METHODOLOGICAL PROCEDURES}

Considering the purpose of analyzing the evolution and the social and intellectual structure of relationship marketing/CRM scientific field, in order to provide an overview of the current research and to identify future avenues of investigation, we performed a systematic review and bibliometric analysis. 
Systematic review is a robust method used to identify and analyze the scientific production of a specific theme, helping scholar to organize and summarize information about a subject (Cronin, Ryan, \& Coughlan, 2008; Kitchenham, 2004), resorting to a qualitative approach to synthesize previous research (Schmidt, 2008). Additionally, we decided to perform a bibliometric analysis, following a quantitative perspective to map the relationship marketing/CRM scientific research, classifying and representing the elements of the field, such as main articles, authors and journals (Zupic \& Carter, 2015). According to these scholars, bibliometric analysis are useful in systematic reviews since it helps scholars to identify the most influential papers and journals, mapping the body of knowledge without a subjective bias.

We followed the workflow proposed by Cronin et al. (2008) and its four stages: (i) research design; (ii) definition of inclusion and exclusion criteria; (iii) literature selection; and (iv) analysis.

In the first stage, research design, we developed the research question, which is the main purpose of this paper: analyze the evolution and the social and intellectual structure of relationship marketing/CRM scientific field and build a research agenda. In the second stage, definition of inclusion and exclusion criteria, we choose to systematically analyze the literature on both CRM and relationship marketing, considering the fact CRM is a part of relationship marketing body of knowledge (Frow \& Payne, 2009). We have also decided on the analyzed period, from 2015 to March 2020, covering the years of scientific production since the last science mapping on relationship marketing (Scussel et al., 2017) and CRM (Araújo et al., 2018). In both studies, the last year mapped was 2015.

The third step was literature selection. We selected only papers from scientific journals, peerreviewed, in the database Web of Science, since it privileges high impact journals, increasing the quality of the data (Chadegani et al., 2013). We used the keywords "Relationship Marketing", "Customer Relationship Management" and "CRM" in the first search, with a result of 4.433 papers. Next, we filtered only the results for the areas of knowledge "Business" and "Management" based on our intention to analyze the relationship marketing and CRM papers as a strategic management approach focused on consumer (Frow \& Payne, 2009), in contrast to the use of CRM as an information technology tool, resulting 844 papers. Next, following Kitchenham's (2004) guidance, we accessed the quality of the papers in an attempt to keep in the literature review only the most reliable scientific evidence. In this sense, Zupic and Carter (2015) recommend to include the highest quality journals, as they represent the state of the art of research in a certain subject. These scholars agree that the quality of the papers directly influences the quality of systematic review. Hence, we selected the papers published in journals indexed in the Journal Citation Report (JCR), with 565 works remaining. Lastly, we analyzed title, abstract and keywords of the 565 articles, building a research corpus composed only by studies addressing relationship marketing/CRM as the main subject. The result was 290 papers.

The fourth and last stage was to analyze and summarize the findings. We used the softwares RStudio and Vosviewer to perform the bibliometric analysis of the final 290 articles. In the software RStudio, we used the package 'bibliometrix', which has enabled us to import the data from Web of Science, performing the quantitative analysis and developing the data matrixes. For its turn, the software Vosviewer allowed us to elaborate the visual representation of the bibliometric networks of the analyzed articles: co-citation, bibliometric coupling and co-author relations.

As Zupic and Carter (2015) explain, co-citation is used to connect documents, authors and journals when they appear in the same reference list. This network considers citation an indicative of influence, being co-citation an adequate to reveal important works of the field. Bibliometric coupling is used to connect papers, authors or journals based on shared references: the overlap of references between two or more articles means they have a strong connection. Besides, since it does not need demand citations, bibliometric coupling can be used to analyze publications not cited yet or emerging fields. Finally, co-authors relation provide evidence of collaboration, revealing the social structure of the scholars of the field (Zupic \& Carter, 2015). 


\section{ANALYSIS AND DISCUSSION OF THE FINDINGS}

The first findings concern the productivity of the analyzed period - January 2015 to March 2020. This was a productive year for the literature, with 290 articles, an average of 55 articles per year in the last five years, as Figure 1 illustrates. The year of 2018 was the most productive year and, although 2019 shows a slightly decrease, we can interpret there is a consistent effort in relationship marketing/CRM scientific production. Note the results regarding the year of 2020 is partial and represent only the publications from January to March 2020.

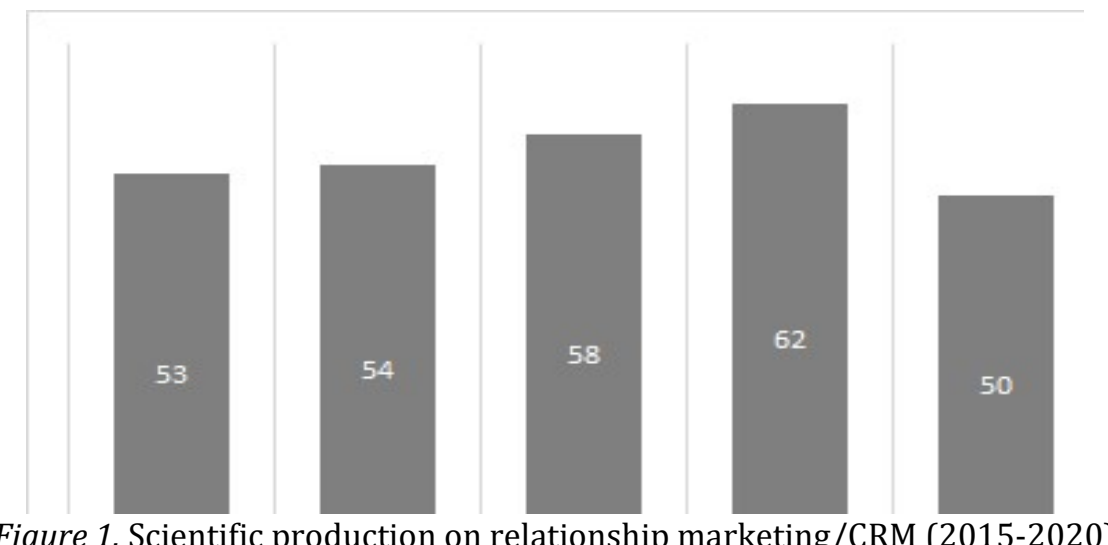

Figure 1. Scientific production on relationship marketing/CRM (2015-2020)

Afterwards, we analyzed the most productive countries. The United States lead the ranking with 45 publications, followed by China with 27 papers (18 papers in co-authorship with other countries). Next, there is Australia with 22 papers, United Kingdom (21), Taiwan (18), Spain (16), Canada (11), France (11), Germany (9) and Finland (8). Figure 2 illustrates these findings, covering $73 \%$ of the scientific articles on relationship marketing/CRM.

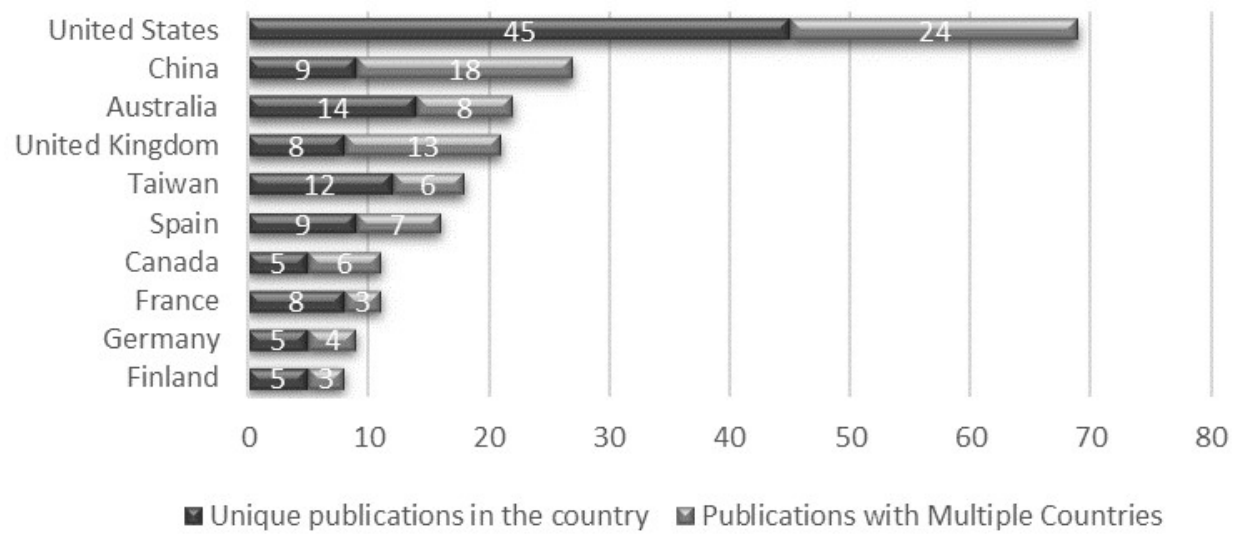

Figure 2. Top ten countries in relationship marketing/CRM research

These findings allow us to observe that the development of relationship marketing/CRM research is associated to international partnership between countries and institutions. Thus, in order to comprehend the way such partnerships are established, we developed a co-authorship analysis. According to Zupic and Carter (2015), this analysis enables the exam of the social networks between scholars around the world who collaborate in a theme's scientific production. These authors also explain that these networks of collaboration reveal the social ties of the research field based on institutional affiliation and geographical location. We performed a co-author analysis using the software RStudio, encompassing the 20 most productive countries regarding publications in international co-authorship, as Figure 3 shows. 


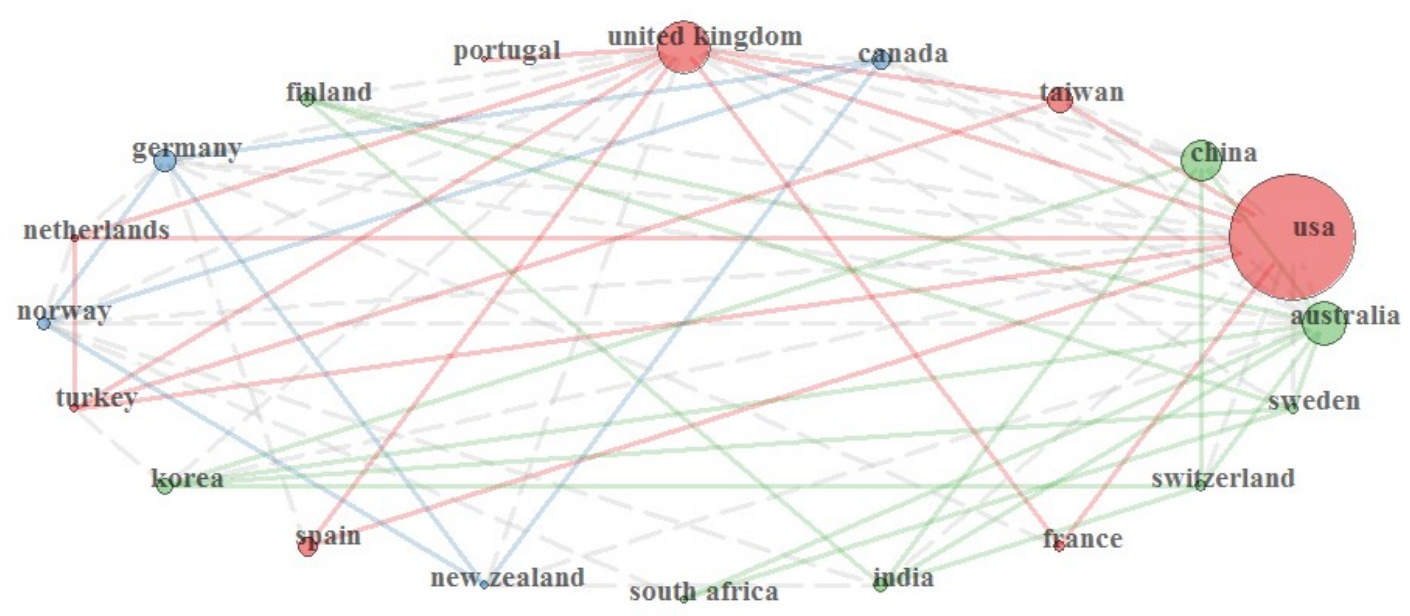

Figure 3. International co-authorship map

Our findings demonstrate that, among the most productive countries, United States, United Kingdom, Australia and China stand out for establishing international partnerships in relationship marketing/CRM research, an increasingly desirable trend in the academic world. We observe that United States, Taiwan, Turkey, Spain, France and the Netherlands have a strong tie as well. For their turn, China, Australia, India, South Korea and Finland form another research community. Lastly, New Zealand, Germany, Canada and Norway also contribute to the development of scientific studies on relationship marketing/CRM. We highlight that, in the case of United States, despite the protagonism of the country leading the research and establishing partnership with other countries such as China, Australia and Canada, these collaborations are less frequent and, for this reason, they do not emerge in the international co-authorship map (Figure 3).

Regarding the most productive authors in this period, we identified Professor V. Kumar, from Georgia State University (USA), and Professor Robert W. Palmatier, from University of Washington (USA), as the leading researchers in this period, with four published articles each. Seven other scholars arise in this concern: Roya Rahimi (University of Wolverhampton, UK), Piyush Sharma (Curtin Business School, Australia), Yong Wang (University of Ohio, USA), Jochen Wirtz (National University of Singapore, Singapore), Song Yang (University of South Australia, Australia), Jonathan Z. Zhang (University of Washington, USA) and Zuopeng Zhang (State University of New York, USA).

From this, we understand that relationship marketing/CRM research is no longer a body of knowledge concentrated in four schools of thought - the North-American, Scandinavian, AngloAustralian and the Industrial Marketing and Purchase Group (Payne, 1995), since research on this topic has expanded in the world, privileging intellectual groups, as we will further discuss, in contrast with geographic communities. However, considering the categorization from Payne (1995) and the fact that the North-American orientation is in line with the consumer perspective, it is reasonable to say that the leading approach of relationship marketing/CRM studies emphasizes consumer centricity.

The next step is the ranking of the most productive journals, as Table 2 demonstrates.

Table 2

Top 5 sources of relationship marketing knowledge

\begin{tabular}{lcc}
\hline \multicolumn{1}{c}{ Journal } & Number of Articles & \% \\
\hline Industrial Marketing Management & 21 & $7,24 \%$ \\
Journal of Business \& Industrial Marketing & 21 & $7,24 \%$ \\
Journal of Business Research & 17 & $5,86 \%$ \\
Journal of the Academy of Marketing & 14 & $4,82 \%$ \\
Science & 13 & $4,48 \%$ \\
International Journal of Bank Marketing & & \\
\hline
\end{tabular}


Leading the ranking, the Industrial Marketing Management and the Journal of Business \& Industrial Marketing have 21 publications each and, in combination, share almost 15\% of the research on relationship marketing/CRM on the analyzed period. Regarding the impact factor, the Industrial Marketing Management presents 4.779 and the Journal of Business \& Industrial Marketing has 1.961. In third place, the Journal of Business Research published 17 papers, with an impact factor of 4.028.

The Journal of the Academy of Marketing Science, the journal with the highest impact factor of the ranking (Table 2), published 14 papers. Lastly, the International Journal of Bank Marketing, with the impact factor of 2.196, has 13 publications. Note that the impact factor we use to analyze the journals are based on the values shared by the Journal Citation Reports (JCR) in 2018, the last data update.

In reference to the most cited articles during the analyzed period, Table 3 presents a ranking composed by the Top 5 papers concerning their impact on relationship marketing/CRM research.

Table 3

Top 5 articles

\begin{tabular}{|c|c|c|c|}
\hline Article & Authorship & Citations & $\begin{array}{c}\text { Citations by } \\
\text { year }\end{array}$ \\
\hline $\begin{array}{l}\text { From social to sale: the effects of firm- } \\
\text { generated content in social media on } \\
\text { customer behavior }\end{array}$ & $\begin{array}{l}\text { Kumar, Bezawada, Rishika, } \\
\text { Janakirama and Kannan } \\
(2016)\end{array}$ & 134 & 26,8 \\
\hline $\begin{array}{l}\text { S-D logic-informed customer engagement: } \\
\text { integrative framework, revised } \\
\text { fundamental propositions, and application } \\
\text { to CRM }\end{array}$ & $\begin{array}{l}\text { Hollebeek, Srivastava and } \\
\text { Chen (2019) }\end{array}$ & 104 & 52 \\
\hline $\begin{array}{l}\text { The effect of website features in online } \\
\text { relationship marketing: a case of online } \\
\text { hotel booking }\end{array}$ & Bilgihan and Bujisic (2015) & 72 & 12 \\
\hline $\begin{array}{l}\text { Building with bricks and mortar: the } \\
\text { revenue impact of opening physical stores } \\
\text { in a multichannel environment }\end{array}$ & Pauwels and Neslin (2015) & 65 & 10,83 \\
\hline $\begin{array}{l}\text { The antecedents of customer loyalty: a } \\
\text { moderated mediation model of customer } \\
\text { relationship management quality and } \\
\text { brand image }\end{array}$ & $\begin{array}{l}\text { Nyadzayo and Khajehzadeh } \\
\text { (2016) }\end{array}$ & 53 & 10,6 \\
\hline
\end{tabular}

The study with the highest number of citations had the objective of investigating the impact of the content that firms share on social media, suggesting a positive effect between social media content and consumer buying behavior (Kumar, Bezawada, Rishika, Janakiraman \& Kannan, 2016). The second most cited article discusses the development of an integrative structure combining service-dominant logic and consumer engagement in order to develop consumer centricity, in terms of interactions and relationships management (Hollebeek, Srivastava \& Chen, 2019).

In third position, Bilgihan and Bujisic (2015) developed a model to investigate the relation between online resources and consumers' commitment and loyalty. Pauwels and Neslin (2015), with the fourth most cited papers, explored the best channels to interact with customers, addressing the impact of multichannel strategies (online and physical stores) on firms' profitability, acquisition of new clients and purchase frequency. Finally, Nyadzayo and Khajehzadeh (2016) focused on the effects of CRM quality on service quality, customer satisfaction, customer value loyalty and brand image.

The next step of our systematic review was to identify the main constructs studied under the relational perspective. For this purpose, we analyzed the most frequent keywords of the 290 articles, building a word-cloud in the software RStudio. Figure 4 shows the most frequent words (the stronger the word in the word-cloud, the highest is the frequency of the construct): satisfaction, commitment, impact, quality, performance, loyalty, model and consumer. 


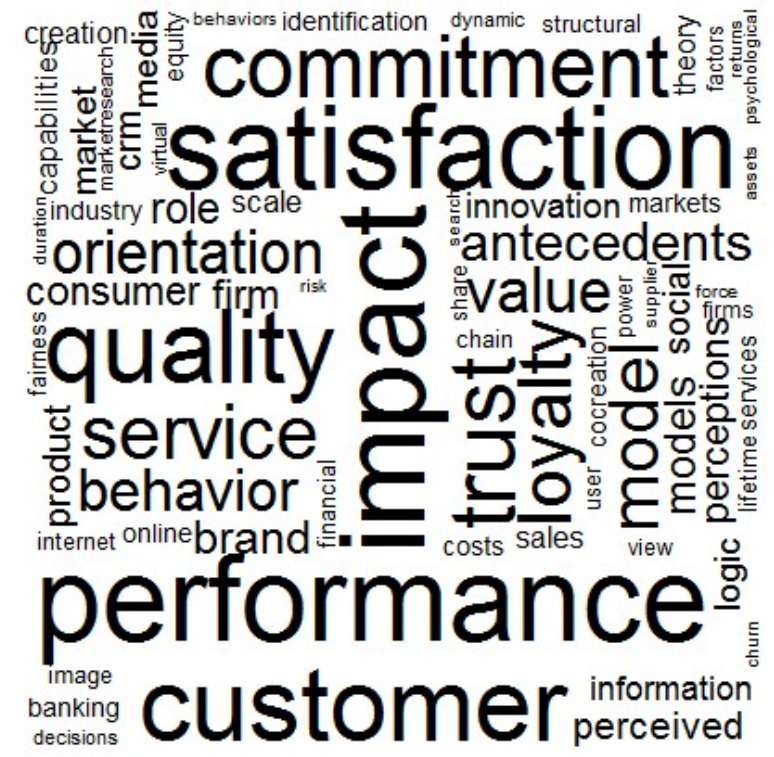

Figure 4. The most studied constructs under the relational perspective

The analysis of Figure 4 indicates the predominance of studies emphasizing consumer satisfaction, commitment and loyalty, in line with the other findings of this paper that point out consumer centricity. In addition, the frequency of the words impact, quality and performance reinforces the strategic focus of relationship marketing/CRM, leading us to understand that the shift from a traditional to a relational perspective, putting the consumer in the heart of organizational strategy (Demo et al., 2015) generates positive outcomes that contribute to the firms' competitive advantage. We also highlight the appearance of the words online and internet, converging to the rise of relationship marketing/CRM in the digital environment, especially social media, which has emerged as a new way of interaction between consumers and firms (Malthouse et al., 2013; Trainor et al., 2014). In this regard, we note the increase of digital marketing as another relational strategy to develop longterm and lucrative relationships.

The final analysis in this systematic review is a bibliographic coupling. As explained by Zupic and Carter (2015), the bibliographical coupling uses information from a systematic review in order to construct a visual representation of a science field, revealing its intellectual structure. According to the authors, this objective measure of scientific literature evaluation helps researchers to identify research networks and shared interests. In this study, we performed a bibliographical coupling to verify the way the articles are connected through cluster analysis, using the software Vosviewer (version 1.6.9). The bibliographical coupling analysis generated five clusters, colored red, purple, yellow, green and blue, as Figure 5 and Table 4 illustrates.

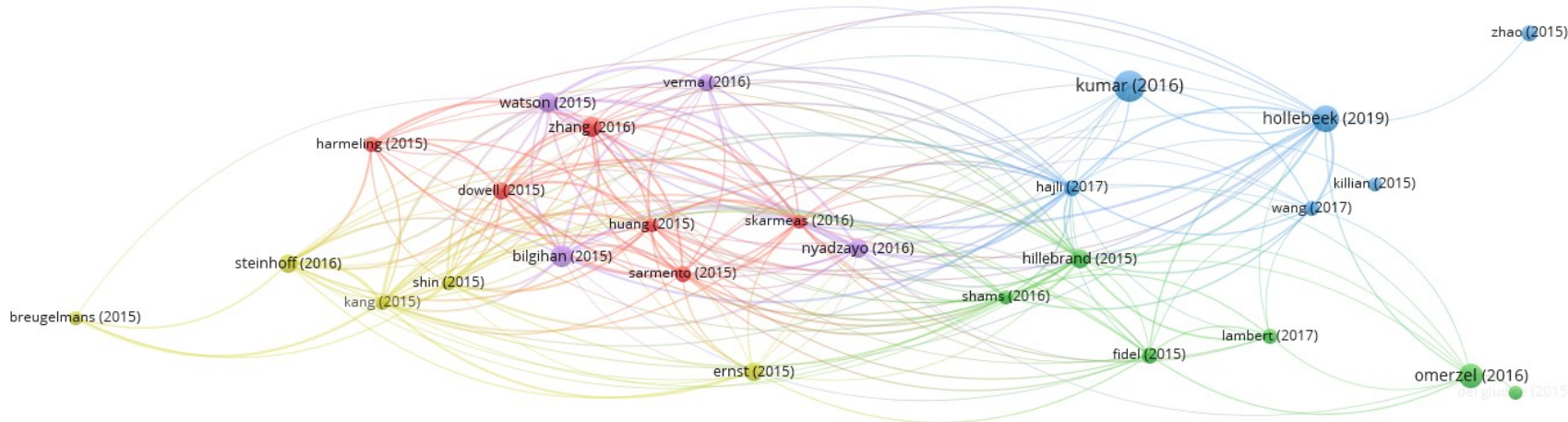

Figure 5. Bibliographical Coupling 
Table 4

Bibliographical Coupling' Clusters

\begin{tabular}{|c|c|c|c|}
\hline $\begin{array}{l}\text { Cluster } \\
\text { color }\end{array}$ & Thematic & Authors & Trends \\
\hline Red & $\begin{array}{l}\text { Business-to- } \\
\text { business } \\
\text { market (B2B) }\end{array}$ & $\begin{array}{l}\text { Dowell, Morrison and Heffernan } \\
\text { (2015) } \\
\text { Simões and Farhangmehr (2015) } \\
\text { Zhang, Watson Iv, Palmatier and } \\
\text { Dant (2016) }\end{array}$ & $\begin{array}{l}\text { Studies focused on B2B } \\
\text { Trust in B2B relationships } \\
\text { B2B interactions }\end{array}$ \\
\hline Purple & $\begin{array}{l}\text { Customer } \\
\text { loyalty }\end{array}$ & $\begin{array}{l}\text { Watson, Beck, Henderson and } \\
\text { Palmatier (2015) } \\
\text { Nyadzayo and Khajehzadeh (2016) } \\
\text { Bilgihan and Bujisic (2015) }\end{array}$ & $\begin{array}{c}\text { Relational strategies in customer } \\
\text { loyalty } \\
\text { Role of loyalty to marketing variables } \\
\text { E-loyalty }\end{array}$ \\
\hline Yellow & $\begin{array}{l}\text { Relationship } \\
\text { marketing/CRM } \\
\text { strategies }\end{array}$ & $\begin{array}{l}\text { Breugelmans et al (2015) } \\
\text { Kang, Alejandro and Groza (2015) } \\
\text { Steinhoff and Palmatier (2016) } \\
\text { Grönroos (2009) } \\
\text { Casidy and Wymer (2016) } \\
\text { Zhang et al. (2016) }\end{array}$ & $\begin{array}{l}\text { Loyalty programs and profitability } \\
\text { Synthetic loyalty }\end{array}$ \\
\hline Green & $\begin{array}{l}\text { Theoretical } \\
\text { studies } \\
\text { frameworks } \\
\text { and models }\end{array}$ & $\begin{array}{l}\text { Hillebrand, Driessen and Koll } \\
(2015) \\
\text { Shams (2016) }\end{array}$ & $\begin{array}{l}\text { Relationship marketing and } \\
\text { stakeholders } \\
\text { Strategic relationship marketing }\end{array}$ \\
\hline Blue & New digital era & $\begin{array}{l}\text { Killian and McManus (2015) } \\
\text { Wang and Kim (2017) } \\
\text { Kumar et al. (2016) } \\
\text { Zhao and Balagué (2015) } \\
\end{array}$ & $\begin{array}{c}\text { Social media } \\
\text { Online context } \\
\text { Mobile marketing }\end{array}$ \\
\hline
\end{tabular}

The red cluster is in the center of Figure 5, and it encompasses the studies focused on the business-to-business market (B2B), a perspective that covers the trust in the relationship between firms (Dowell, Morrison, \& Heffernan, 2015) and the interactions that leads companies to a better organizational practice (Simões \& Farhangmehr, 2015). The B2B perspective has the purpose of finding the best strategies conducting to organizational relationships in order to achieve better results (Zhang, Watson Iv, Palmatier, \& Dant, 2016).

The purple cluster reunites the works about the impact of relational strategies in customer loyalty (Watson, Beck, Henderson, \& Palmatier, 2015) and the role of loyalty to other marketing variables such as brand image (Nyadzayo \& Khajehzadeh, 2016). We also observed the rise of the concept e-loyalty, regarding the acquisition of trust and loyalty of consumers in the digital environment, through relational strategies adapted to the online context (Bilgihan \& Bujisic, 2015).

The yellow cluster embraces research emphasizing the adoption and implementation of relationship marketing/CRM strategies, such as loyalty programs and its impact on profitability (Breugelmans et al, 2015; Kang, Alejandro \& Groza, 2015; Steinhoff \& Palmatier, 2016). This cluster also covers investigations about synthetic loyalty, which means consumer behavior guided exclusively by financial outcomes, like loyalty programs, considered a basic level of relationship marketing as it limits the relational benefits brought by long-term relationships between firms and consumers (Grönroos, 2009). It is important to mention that the loyalty analyzed in the yellow cluster contrasts with the loyalty from the purple cluster, being the latter focused on an authentic relationships based on attitudinal loyalty, in reference to the emotional bond that emerges from trust and identification with the brand, beyond the utilitarian benefits (Casidy \& Wymer, 2016; Zhang et al., 2016).

For its turn, the green cluster comprises theoretical studies and the development of frameworks and models with the objective of conceptual understanding of relationship marketing/CRM. In this perspective, Hillebrand, Driessen and Koll (2015) presented the main theories of marketing literature conducting to good relationships between a company and its stakeholders, confirming relationship marketing is one of them. According to Shams (2016), there is an agreement in 
literature that relationship marketing is a strategic perspective strongly related to organizational performance and sustainable competitive advantage.

Lastly, the blue cluster integrate the articles dedicated to understand the relational approach in the new digital era, embodying the research about social media (Killian \& McManus, 2015; Wang \& Kim, 2017), adaptation of strategy to the online context (Kumar et al., 2016) and the rise of mobile marketing (Zhao \& Balagué, 2015).

Together, the five clusters represent the intellectual structure of the relationship marketing/CRM scientific field. Note that the red cluster (B2B perspective) is in the center of Figure 5, with strong connections with the purple cluster (loyalty). The dialogue between such perspectives represent a structural content of relationship marketing/CRM since they connect the other clusters. From this, we understand that relationship marketing/CRM research follows a strategic perspective, with focus on customer loyalty, in line with its conceptual foundations (Scussel et al., 2017). Close to these nods, there is the green cluster (theoretical foundations of relationship marketing/CRM), reinforcing the idea of this construct as an outcome of organizational efforts concerning developing competitive advantage from the interaction with consumers.

\section{RESEARCH AGENDA PROPOSITION}

The analysis of the evolution and the social and intellectual structure of relationship marketing/CRM scientific field has given us the understanding of the current state of the literature and the opportunity to draw a research agenda for the near future. Table 5 highlights the themes and primary questions for the relationship marketing/CRM scientific field.

Table 5

Research agenda in relationship marketing/CRM

Theme Source Research questions

How do specific cultural particularities affect the adoption, implementation and evaluation of

Relationship marketing in emerging economies
Social structure of the field (as seen in Figure 2 and 3)

relationship marketing and CRM strategies? What's the impact of relationship marketing on competitive advantages?

How's the research network between emerging economies on relationship marketing studies?

How can social media interaction between firms and consumers affect companies' performance? How do social media affect the relationship with consumers? Do they improve loyalty? How can that be measured?

Are companies prepared for the new digital era?

Are the marketing strategies more effective?

Does companies' online behavior influence the consumer behavior?

Social Media and

Online relationship marketing/CRM
Most cited articles Blue cluster
How does the relationship between consumer and social media affect the relationship between consumer and company?

How can social media CRM be applied in the context of local and small companies?

What drives the consumer behavior on e-commerce relationships?

How did social media's role affected the relationship between companies and consumers during the pandemic?

How can strong connection between relationship

Relatinship marketing/CRM and Purple and yellow clusters loyalty
marketing/CRM and organizational strategy improve consumer satisfaction, trust and loyalty? How can consumer satisfaction, trust and loyalty be 
improved on the online context?

How can multiple touchpoints affect enhance the relationship with the consumer?

Can multiple touchpoints be strategies used in the COVID-19 scenario?

Has the consumer loyalty been affected by the pandemic?

How can the fast changing digital era scenario affect the field of relationship marketing and CRM? Does the field

Theoretical developments

Green cluster require concepts adaptations?

How can empirical and managerial studies confirm that?

How did the pandemic affect the relationships between consumers and companies?

How B2B relationships can be enhanced within the

B2B Perspective Red cluster online and social media environment?

How did the B2B perspective affect relationships during the COVID-19 pandemic?

Concerning the social structure of the field, we note the predominance of developed countries and American and Australian researchers as the most productive in relationship marketing/CRM research in the last five years. These arguments corroborate previous literature reviews that pointed out the hegemony of such countries, as well as the importance of international partnerships for further development of the construct. For this reason, we suggest future studies to embrace the relational perspective in emerging economies, such as Latin American and African countries, which certainly have specific cultural particularities that will affect the adoption, implementation and evaluation of relationship marketing/CRM strategies. Moreover, since this construct a driver of sustainable competitive advantage (Demo et al., 2015; Payne, 2012; Scussel et al., 2017), it is plausible to say that this approach may lead companies from these countries or global companies operating in such communities to impact on their human and economic development. Additionally, we recommend the joint efforts between scholars and institutions around the globe in order to build a broader research network.

Considering the most cited papers (Table 3), we understand they play an important role in relationship marketing/CRM research development. Following the lead of these articles, we foresee social CRM, regarding the usage of social media as a new and increasing context of interaction between firms and consumers in the digital era (Trainor et al., 2014). As Malthouse et al. (2013) explain, social media has brought closer companies and internet users, enhancing the opportunities of connection and communication in a fast and dynamic way. In alignment to the results obtained in the blue cluster (Figure 5), the online environment is an important content in relationship marketing/CRM research to be further explored.

Our research agenda also comprises a synthesis of the most cited papers in this perspective. Bilgihan and Bujisic (2015) suggest works about online behavior in different motivational contexts for consumers, explaining that experimental research should be a starting point to understand the impact of virtual relational resources on consumer behavior. For Kumar et al. (2016), the analysis of consumers' preferred social media and the nature of the relationship with each social media will contribute to understand the relationships in the online context. As proposed by Hollebeek et al. (2019), the study of consumer engagement in a company's social media profile should be investigated in terms of its effect on organizational performance. Thus, we believe that the acquisition, retention and development of customers and firms in the online scenario should be taken into account in further investigations, addressing the combination of technology and relational strategies in order to develop the customer centric approach that will conduct firms' performance in the digital field.

As proposed by Pawels and Nesslin (2015), the matter of relational strategies' efficiency in the multichannel scenario is a literature gap. For their turn, Nyadzayo and Khajehzadeh (2016) recommend the identification and comprehension of the antecedents of relationship marketing/CRM 
and the impact of this construct in loyalty. Combining these suggestions with the results from the purple cluster (customer loyalty) and the yellow cluster (adoption and implementation strategies), we see a strong connection between relationship marketing/CRM and organizational strategy, with the main purpose of achieving consumer satisfaction, trust and loyalty (Scussel et al., 2017). Nevertheless, with the possibilities brought by social media, e-commerce and multichannel strategy, understand the drivers of consumer preference is insufficient, and we highlight the challenge of identifying the drivers of consumer loyalty and further using such information to create offers that meet consumers' needs, demands, desires and economic realities.

This discussion guides us to the opportunities of interaction with customers, especially concerning the role of technology in creating multichannel possibilities (Pauwels \& Neslin, 2015). In this sense, we advise scholars to address the content of consumption journey in their relationship marketing/CRM studies. Since this topic enables the identification of the touchpoints between consumers and firms during the stages of search, purchase and after purchase (Lemon \& Verhoef, 2016), it gives the opportunity for firms to interact with consumers in multiple touchpoints, finding the opportunity to develop and enhance their relationships.

Considering the relevance of theoretical developments showed by the green cluster (Figure 5), we believe that the empirical development in relationship marketing/CRM must be followed by the theoretical comprehension of its philosophy and purpose. The fast changing scenario in which consumers and firms relate and the new possibilities brought by the digital and the multichannel context constantly create new tracks in this scientific field, demanding conceptual development in parallel with empirical discoveries and managerial practice evolution.

The volume of articles creating the red cluster (Figure 5) demonstrates the relevance of the B2B perspective, a result that is expected considering the roots of relationship marketing in the relations between firms (Demo et al., 2015). When we compare the nods of the red cluster with the other nods, with the proper support of literature (Demo et al., 2015; Grönroos, 2009; 2017; Scussel et al., 2017), we comprehend this is a mature topic under relationship marketing/CRM research. This means the other clusters have an agenda to purse, as we discussed in this section, with a point of convergence: the focus on the consumer.

\section{CONCLUSION}

The objective of this paper was to analyze the evolution and the social and intellectual structure of relationship marketing/CRM scientific field, an effort that guided us into the development of a research agenda, in which we address future avenues of investigation. The analysis of 290 published between 2015 and 2020 allowed us to identify the institutional characteristics of the scientific production, the international partnerships and networks of collaboration, the main sources of knowledge on the theme, the most relevant papers in the area and the hot topics on relationship marketing/CRM literature. The exam of these findings enabled us to build a research agenda for scholars, research groups and practioners, reaching the purpose of this work.

We understand that the focus on journal papers and the choice for journals with high impact and only from one database, although the most expressive and relevant (WoS), is a limitation. However, we justify our decision of excluding conference papers since they are work in progress, and we followed the purpose of mapping the highest level of scientific information about relationship marketing/CRM.

Regarding contributions, this study sheds light into the current research on relationship marketing/CRM, contributing to the theoretical and empirical development of its literature by indicating the future avenues of research based on the gaps identified. In addition, beginning scholars can benefit from our findings to understand the foundations of relationship marketing/CRM literature, find a guidance for their first steps in scientific research and understand the dynamics of this social field in order to find groups with similar interests to establish partnerships. We also foresee managerial implications, since the avenues identified in this work can help managers to comprehend the trends in the relational context, improving the formulation of organizational strategies and creating relationships that are more fruitful with their customers. 
This article advances the previous literature reviews on relationship marketing and CRM, signalizing new avenues to be followed, new insights and research trends, drawing a theoretical framework that allows managers to rethink their practice and scholars to carry on research increasingly aligned with the needs of the consumer society.

\section{References}

Agariya, A. K., \& Singh, D. (2012). CRM Scale Development and Validation in Indian Insurance Sector. The Journal of Internet Banking and Commerce, 17(2), 1-21.

Araújo, C. C. S., Pedron, C. D., \& Picoto, W, N. (2018) What's Behind CRM Research? A Bibliometric Analysis of Publications in the CRM Research Field. Journal of Relationship Marketing, 17(1), 2951.

Benouakrim, H., \& El Kandoussi, F. (2013). Relationship marketing: literature review. International Journal of Science and Research, 2(10), 148-152.

Berry, L. L. (1995). Relationship marketing of services-growing interest, emerging perspectives. Journal of the Academy of marketing science, 23(4), 236-245.

Bilgihan, A., \& Bujisic, M. (2015). The effect of website features in online relationship marketing: A case of online hotel booking. Electronic commerce research and applications, 14(4), 222-232.

Bowen, J.T. and S.L.C. McCain (2015). Transitioning loyalty programs: A commentary on "the relationship between customer loyalty and customer satisfaction. International Journal of Contemporary Hospitality Management, 27(3): 415-430.

Breugelmans, E., Bijmolt, T. H., Zhang, J., Basso, L. J., Dorotic, M., Kopalle, P., ... \& Wünderlich, N. V. (2015). Advancing research on loyalty programs: a future research agenda. Marketing Letters, 26(2), 127-139.

Buttle, F., \& Maklan, S. (2019). Customer relationship management: concepts and technologies. Routledge.

Campbell, A. J. (2003). Creating customer knowledge competence: managing customer relationship management programs strategically. Industrial Marketing Management, 32(2003), 375-383.

Casidy, R., \& Wymer, W. (2016). A risk worth taking: Perceived risk as moderator of satisfaction, loyalty, and willingness-to-pay premium price. Journal of Retailing and Consumer Services, 32, 189-197.

Chadegani, A., Salehi, H., Yunus, M., Farhadi, H., Fooladi, M., Farhadi, M., \& Ale Ebrahim, N. (2013). A comparison between two main academic literature collections: Web of Science and Scopus databases. Asian Social Science, 9(5), 18-26.

Cronin, P., Ryan, F., \& Coughlan, M. (2008). Undertaking a literature review: a step-by-step approach. British Journal of Nursing, 17(1), 38-43.

Das, K. (2009). Relationship marketing research (1994-2006). Marketing Intelligence \& Planning, 27(3), 326-363.

Demo, G., \& Lopes, C. (2014). Guaraná Antarctica e cerveja Skol: Desenvolvimento e validação de escalas de relacionamento com clientes. In Perspectivas Contemporâneas em Marketing. Portugal: TMS Conference Series, (pp. 183-199).

Demo, G., \& Rozzett, K. (2013). Customer Relationship Management scale for the Business-to Consumer market: exploratory and confirmatory validation and models comparison. International Business Research, 6(11), 29-42.

Demo, G., Batelli, L., \& Albuquerque, P. (2015). Customer Relationship Management scale for Video Games' Players: Exploratory and ordinal factor analysis. Revista Organizações em Contexto, 11(22), 285-312.

Demo, G., Fogaça, N., \& Cardoso, H. (2017). Desenvolvimento e validação de uma escala de relacionamento para clientes de Telecom. Negócios em Projeção, 8(2), 28-49.

Demo, G., Fogaça, N., Ponte, V., Fernandes, T., \& Cardoso, H. (2015). Marketing de Relacionamento (CRM): estado da arte, revisão bibliométrica da produção nacional de primeira linha, 
institucionalização da pesquisa no Brasil e agenda de pesquisa. Revista de Administração Mackenzie, 16(5), 127-160.

Demo, G., Rozzet, K., Fogaça, N., \& Souza, T. (2018). Development and validation of a Customer Relationship Scale for Airline Companies. Brazilian Business Review, 15(2), 105- 119.

Demo, G., Watanabe, E. A. M., Chauvet, D. C. V., \& Rozzett, K. (2017). Customer Relationship Management Scale for the B2C Market: a cross-cultural comparison. RAM. Revista de Administração Mackenzie, 18(3), 42-69.

Dowell, D., Morrison, M., \& Heffernan, T. (2015). The changing importance of affective trust and cognitive trust across the relationship lifecycle: A study of business-to-business relationships. Industrial Marketing Management, 44, 119-130.

Frow, P. E., \& Payne, A. F. (2009). Customer relationship management: a strategic perspective. Journal of Business Market Management, 3(1), 7-27.

Grönroos, C. (1994). From marketing mix to relationship marketing: Towards a paradigm shift in marketing. Asia-Australia Marketing Journal, 2(1), 9-29.

Grönroos, C. (2009). Marketing as promise management: regaining customer management for marketing. Journal of Business \& Industrial Marketing, 24(5/6), 351-359.

Grönroos, C. (2017). Relationship marketing readiness: theoretical background and measurement directions. Journal of Services Marketing, (31)3, 218-225.

Harker, M. J., \& Egan, J. (2006). The past, present and future of relationship marketing. Journal of marketing management, 22(1-2), 215-242.

Heck, E. V. (2019). Big Data and Disruptions in Business Models. Revista de Administração de Empresas, $59(6), 430-432$.

Hillebrand, B., Driessen, P. H., \& Koll, O. (2015). Stakeholder marketing: theoretical foundations and required capabilities. Journal of the Academy of Marketing Science, 43(4), 411-428.

Hollebeek, L. D., Srivastava, R. K., \& Chen, T. (2019). SD logic-informed customer engagement: integrative framework, revised fundamental propositions, and application to CRM. Journal of the Academy of Marketing Science, 47(1), 161-185.

Kang, J., Alejandro, T. B., \& Groza, M. D. (2015). Customer-company identification and the effectiveness of loyalty programs. Journal of Business Research, 68(2), 464-471.

Killian, G., \& McManus, K. (2015). A marketing communications approach for the digital era: Managerial guidelines for social media integration. Business Horizons, 58(5), 539-549.

Kitchenham, B. (2004). Procedures for performing systematic reviews. Keele, UK, Keele University, 33(2004), 1-26.

Kumar, A., Bezawada, R., Rishika, R., Janakiraman, R., \& Kannan, P. K. (2016). From social to sale: The effects of firm-generated content in social media on customer behavior. Journal of Marketing, $80(1), 7-25$.

Lemon, K. N., \& Verhoef, P. C. (2016). Understanding customer experience throughout the customer journey. Journal of Marketing, 80(6), 69-96.

Maçada, A. C. G., Brinkhues, R. A., \& Freitas Junior, J. C. S. (2019). Information Management Capability and Big Data Strategy Implementation. Revista de Administração de Empresas, 59(6), 379-388. Epub January 10, 2020.

Magrini, G. B. M., \& Demo, G. (2017). Clientes fiéis, supermercados mais rentáveis: desenvolvimento e validação de uma escala de relacionamento com clientes de supermercados-erc super. Revista Gestão Industrial, 12(4).

Malthouse, E. C., Haenlein, M., Skiera, B., Wege, E., \& Zhang, M. (2013). Managing customer relationships in the social media era: Introducing the social CRM house. Journal of Interactive Marketing, 27(4), 270-280.

Marriott, H. R., Williams, M. D., \& Dwivedi, Y. K. (2017). What do we know about consumer m-shopping behaviour? International Journal of Retail \& Distribution Management, 45(6), 568-586.

Mishra, A., \& Mishra, D. (2009). Customer Relationship Management: implementation process perspective. Acta Polytechnica Hungarica, 6(40), 83-99.

Mohammadhossein, N., \& Zakaria, N. H. (2012). CRM benefits for customers: literature review (20052012). International Journal of Engineering Research and Applications, 2(6), 1578-1586. 
Morgan, R. M., \& Hunt, S. D. (1994). The commitment-trust theory of relationship marketing. Journal of marketing, 58(3), 20-38.

Ngai, E. W. T. (2005). Customer relationship management research (1992-2002): An academic literature review and classification. Marketing Intelligence \& Planning, 23(6), 582-605.

Nyadzayo, M. W., \& Khajehzadeh, S. (2016). The antecedents of customer loyalty: A moderated mediation model of customer relationship management quality and brand image. Journal of Retailing and Consumer Services, 30, 262-270.

Pauwels, K., \& Neslin, S. A. (2015). Building with bricks and mortar: The revenue impact of opening physical stores in a multichannel environment. Journal of Retailing, 91(2), 182-197.

Payne, A., \& Frow, P. (2005). A strategic framework for customer relationship management. Journal of Marketing, 69(4), 167-176.

Payne, A., \& Frow, P. (2017). Relationship marketing: looking backwards towards the future. Journal of Services Marketing, 31(1), 11-15. https://doi.org/10.1108/JSM-11-2016-0380

Payne, A. (1995). Relationship marketing: a broadened view of marketing. In A. Payne (Ed.). Advances in relationship marketing (pp. 29-40). Kogan Page.

Payne, A. (2012). Handbook of CRM: Achieving excellence in customer management. Oxford: Elsevier

Reimann, M., Schilke, O., \& Thomas, J. (2010). Customer relationship management and firm performance: The mediating role of business strategy. Journal of the Academy of Marketing Science. 38. 326-346.

Ross, B. (2009). Ten tips to winning at consumer centricity: for retailers and manufacturers. Journal of Consumer Marketing, 26(6), 450-454.

Roy, S., \& Moorthi, Y. L. R. (2017). Technology readiness, perceived ubiquity and M-commerce adoption. Journal of Research in Interactive Marketing, 11(3), 268-295.

Rozzett, K., \& Demo, G. (2010). Desenvolvimento e validação fatorial da escala de relacionamento com clientes (ERC). RAE-Revista de Administração de Empresas, 50(4), 383-395.

Samiee, S., Chabowski, B. R., \& Hult, G. T. M. (2015). International relationship marketing: Intellectual foundations and avenues for further research. Journal of International Marketing, 23(4), 1-21.

Sarmento, M., Simões, C., \& Farhangmehr, M. (2015). Applying a relationship marketing perspective to B2B trade fairs: The role of socialization episodes. Industrial Marketing Management, 44, 131141.

Schmidt, F. (2008). Meta-analysis: A constantly evolving research integration tool. Organizational Research Methods, 11(1), 96-113.

Scussel, F. \& Demo, G. (2019). The relational aspects of luxury consumption in Brazil: the development of a Luxury Customer Relationship Perception Scale and the analysis of brand personality influence on relationship perception on luxury fashion brands. Brazilian Business Review, 16(2), 174-190.

Scussel, F. B. C., Petroll, M. M., Semprebon, E., \& Rocha, R. A. (2017). O Que É, Afinal, Marketing de Relacionamento? Uma Proposta de Conceito Unificador. Revista de Ciências da Administração, 19(48), 9-23.

Shams, S. R. (2016). Capacity building for sustained competitive advantage: a conceptual framework. Marketing Intelligence \& Planning, 34(5), 671-691.

Sheth, J. N., \& Parvatiyar, A. (2002). Evolving relationship marketing into a discipline. Journal of relationship marketing, 1(1), 3-16.

Sin, L. Y., Tse, A. C., \& Yim, F. H. (2005). CRM: conceptualization and scale development. European Journal of marketing, 39(11/12), 1264-1290.

Spottke, B., Eck, A., \& Wulf, J. (2016, December). A socio-technical approach to study consumer-centric information systems. Proceedings of the International Conference on Information Systems, Dublin, Ireland, 37.

Steinhoff, L., \& Palmatier, R. W. (2016). Understanding loyalty program effectiveness: managing target and bystander effects. Journal of the Academy of Marketing Science, 44(1), 88-107.

Trainor, K. J., Andzulis, J. M., Rapp, A., \& Agnihotri, R. (2014). Social media technology usage and customer relationship performance: A capabilities-based examination of social CRM. Journal of Business Research, 67(6), 1201-1208. 
Vasconcelos, H., \& Demo, G. (2012). Enchant to Retain: An Instrumental Study about the Relationship between Walt Disney World Parks and its Brazilian customers. In Anais do International Conference on Industrial Engineering and Operations Management, volume 18.

Veloutsou, C., Saren, M., \& Tzokas, N. (2002), Relationship marketing: What if ...? European Journal of Marketing, 36(4), 433-449.

Venter, P., \& van Rensburg, M. (2014). The relationship between marketing intelligence and strategic marketing. South African Journal of Economic and Management Sciences, 17(4), 440-4470.

Wang, Y., \& Feng, H. (2012). Customer relationship management capabilities: Measurement, antecedents and consequences. Management Decision, 50(1), 115-129.

Wang, Z., \& Kim, H. G. (2017). Can social media marketing improve customer relationship capabilities and firm performance? Dynamic capability perspective. Journal of Interactive Marketing, 39, 1526.

Watson, G. F., Beck, J. T., Henderson, C. M., \& Palmatier, R. W. (2015). Building, measuring, and profiting from customer loyalty. Journal of the Academy of Marketing Science, 43(6), 790-825.

Wilson, E. J. \& Vlosky, R. P. (1997). Partnering relationship activities: building theory from case study research. Journal of Business research, 39(1), 59-70.

Zhang, R., G. Li, Z. Wang, \& H. Wang. (2016). Relationship value based on customer equity influences on online group-buying customer loyalty. Journal of Business Research, 69(9), 3820-3826.

Zhang, J. Z., Watson Iv, G. F., Palmatier, R. W., \& Dant, R. P. (2016). Dynamic relationship marketing. Journal of Marketing, 80(5), 53-75.

Zhao, Z., \& Balagué, C. (2015). Designing branded mobile apps: Fundamentals and recommendations. Business Horizons, 58(3), 305-315.

Zupic, I., \& Čater, T. (2015). Bibliometric methods in management and organization. Organizational Research Methods, 18(3), 429-472. 